Jurnal Office: Jurnal Pemikiran Ilmiah dan Pendidikan Administrasi Perkantoran

Vol. 6, No. 2, July-December 2020, Page 131-142

Homepage: http://ojs.unm.ac.id/jo

\title{
A Critique of Aldo Leopold Land Ethic for Environmental Management
}

\author{
Maxwell-Borjor Achuk Eba \\ Department of History and International Studies, University of Calabar, Cross River State, Nigeria \\ Email: raremaxxy@yahoo.com
}

\begin{abstract}
There is no question of doubt that Aldo Leopold (1887-1948) is regarded as the most influential figure in the development of an economic environmental ethics. The cornerstone of his environmental ethics is science. In fact, the science of ecology in the real sense of the term was developed during his life time and it would not be an exaggeration to say that he was the first person to call for a radical rethink of ethics in the light of science. In his collective essays published posthumously as A Sand Country Almanac (1949), the essay 'Land Ethic' included in this book is the systematic presentation of an eco-centric ethics. This work attempt to critique Aldo Leopold Land ethics for environmental management. This work applauds Aldo Leopold 'land ethic' because he sees the ecosystem as an organic wholes and its values implicit in concepts such as integrity and stability, health and well-being. However, this work criticized Aldo Leopold 'Land Ethics' because his view of organic model of ecological systems is inadequate. This is because of the fact that species within an ecosystem could exist outside the organism. Thus, Aldo Leopold 'land ethic' is not holistic enough.
\end{abstract}

keywords: Environmental Ethics, Environmental Management, Land Ethic,

\section{INTRODUCTION}

Before the appearance of Leopold's 'Land Ethic', the society was dominated and influenced by the Lockean view of land as property. However, with the perception of Leopold, our view about land has been changed. We cannot treat the land as a mere object as we did in the past. We cannot treat land as dead property and use it as our own desire as we did in the past. Instead of that, land should be treated and viewed as a living organism that can be perceived as healthy or unhealthy, injured or killed. According to Leopold, it would be wrong on the part of humans to conceive of land as mere soil. Land is not mere soil, nor is it mere property, rather one should realize it as the source of energy that spontaneously flows from land. Leopold says, "Land, then, is not merely soil; it is a fountain of energy flowing through a circuit of soils, plants, and animals" (Jürgens, 2014). Here Leopold speaks of the 'extension of ethics' and in this regard he tells us that 'the land ethic simply enlarges the boundaries of the community to include soils, waters, plants, and animals, or collectively the land" (Heffeman, 1982). Of course, before the appearances of Land Ethic, there was no such claim developed in the realm of environmental ethics. Leopold knows it. He then says that we have no land ethic yet but we are at least nearing to the point of admitting that birds should continue as a matter of biotic right. In this direction we should extend moral consideration with regard to 'biotic rights' to birds, soils, waters, plants and animals. Having said this, Leopold never abandons his conviction that these natural objects can be used as 'resources' that can be managed for human benefit. Thus, it would be difficult to consider Leopold as a defender of animal and plant rights very similar to Singer, Regan and Stone. How can natural resources, such as, soils, waters etc., be reconciled with the moral rights to animals? Certainty, Leopold cannot be placed in the animal right 


\section{Jurnal Office: Jurnal Pemikiran Ilmiah dan Pendidikan Administrasi Perkantoran}

Vol. 6, No. 2, July-December 2020, Page 131-142

camp. However, this apparent inconsistency can be resolved if we read the land ethics of Leopold holistically. According to Leopold, it is not the land, but the land community that is granted moral standing even if individual members of that community can still be treated as resources so long the community itself be respected. The ecological conscience teaches us that humans are nothing but the members of the biotic community rather than the conquerors of nature. Thus, ecology shifts the focus of moral consideration away from individuals and onto biotic wholes. The moral extensions' that has been proposed by Leopold in his Land Ethic does not propose that we simply make room in our moral deliberations for yet another type of individual moral subject. Rather it can be said that after Leopold, we made a radical category shift away from individuals. Instead of individual, we ought to allow moral standing to communities, i.e., land communities. In this regard, Leopold writes, "A thing is right when it tends to preserve the integrity, stability, and beauty of the biotic community. It is wrong when it tends otherwise" (Heffeman, 1982).

\section{LITERATURE REVIEW}

\section{The Concept of the Biotic Pyramid}

In this context, Leopold introduces the 'biotic pyramid' or 'land pyramid' for assisting us to understand the nature of the biotic community. In this regard, Leopold was influenced by Tanseley's ecosystem approach to ecology (Jürgens 2014). The biotic or land pyramid is highly organic structure of both biotic and abiotic elements through which solar energy flows. This structure can be comprehended as a pyramid according to Leopold. In this pyramid, the soil is on the bottom, followed in turn by a plant layer, an insect layer, a bird and rodent layer, and "so on up through the various animal groups to the apex layer, which consists of the larger carnivores" (Walck \& Strong, 2001). It thus seems that species are settled in layers or 'trophic levels' according to the food that they eat. Of course, there must exist numerically more members of a prey species than its predators and as a result of that each successive layer decreases in numerical abundance forming the pyramidal shape of the system. The lines of dependency for food and other services are called food chains. For Leopold, each species, including ourselves, is a link in many chains. The deer eats a hundred plants other than oak, and the cow a hundred plants other than corn. Thus, both are alike in a hundred chains. The so-called pyramid is a tangle of chains. It is extremely complex as to seem disorderly even though the stability of the system proves it to be highly organized structure. Its functioning, thus, depends on the 'cooperation and competition of its diverse parts' (Rolston, 2000).

On the basis of the above observation, we can draw some general normative instructions or guidance. As the biotic pyramid or land pyramid is a complex and highly organized structure, only a 'fool would discard seemingly useless parts'. One has to follow the path of preservation of life-forms. For Leopold, preservation of lifeforms in all their diversity is the first general rule that we ought to follow. Even ecologists find it difficult to understand such complex system. This is mainly because this complex structure has developed through millions of years of evolution and human interference with it should always be humble and embarrassed. Naturally, any change in the system requires that many other elements adjust themselves to it. When this occurs slowly through evolution, the system is self-regulating. When change is introduced brusquely and sadistically, the potential for disaster is real. Another notable insight of Leopold's Land Ethic is that here he favors native plants and animals because they are best suited for a particular locale. Leopold was vastly against reliance on chemical pesticides, herbicides, and fertilizers. He had a sympathetic and healthy relationship to the land. He maintained a close ideal ecological and environmental lifestyle. His feeling about a dead oak tree reflects his intense coherence with the natural world. Leopold mourns the loss of the old tree but at the same time was satisfied to know 
that dozens of its progeny had already set down roots in the nearby woods. After a year of drying, he cut the oak by hand, each pull of the saw cutting through years of the oak's life as captured in its annual rings. Leopold then traces the life of the oak with each pull. At the other end of the cycle, the oak is reduced to ashes in the fireplace while providing heat for the farmhouse. Eventually, the ashes will be returned to the land as compost only to reappear, in time, as a red apple or a fat squirrel bent on planting acorns.

It seems that the death of a single splendid oak tree is sad to Leopold and he tries to comprehend it from a broader perspective. For Leopold, all biotic communities including humans are nothing but just the members of ecological community. Very similar to that, an oak should be honored as a member of ecological community even though it is natural resource and is used for firewood. This is a sort of internal feeling and compassion and nothing else. It is fact that when one oak dies and other species benefit by consuming it. This happens continuously and so the cycle goes on in a harmonious and stable relationship. For Leopold, each member of the community is a resource for the continuation of the lives of others. The death of one will help to give birth to another new life. It is an unavoidable process and that will continue forever. An oak dies, but oaks live on. According to Callicott, one may sense Darwinian roots in the Land Ethic of Leopold (Emmanuel 2020). Here resources are used with an ever ending recycled process. The natural community is characterized by countless of these interdependencies. Its health is characterized by its long-term integrity and stability. The land ethic of Leopold thus appears as a fairly comprehensive theory including both biotic and abiotic communities within the sphere of environment. It also functions as a decision-making process for most environmental and ecological issues. It equally offers normative guidance about issues as diverse as wilderness preservation, pollution, conservation, energy, resource depletion, and so on. Besides, it can circumvent so many counter-intuitive conclusions that would burden the individualistic biocentric approach. The main concern is, of course, to continue a healthy functioning of the environmental system (Edame, Effiong, \& Ackuk, 2014)). Putting everything into perspective, we can say that the Land Ethic of Leopold is thoroughly non-anthropocentric in nature. It is non-anthropocentric in nature because here the superiority of humans has been forfeited completely. According to this theory, men are not supposed to be the measures of everything; rather men are just very similar to any other natural community. It asserts that humans have no special privilege or status in the ecological community. They are reduced from conquerors to mere members. Such type of perception is at par with ecology. There is nothing wrong in treating man like a natural community because it is the reality that each natural community including men is interdependent and inter-related. Thus many would say, that the approach of land ethic of Leopold would be treated as the single most important prerequisite for a sound environmental perspective.

\section{The Holism of the Land Ethic}

Leopold while developing his perception about land ethic says that 'a land ethic implies respect for fellow members and also for the community as such' (Emmanuel 2020). Thus, it seems to us that the land ethic of Leopold has a holistic dimension that is completely foreign to the mainstream modern moral theories going back to Hobbes. The holistic dimension of land ethic, according to Callicott, respect for the community as such in addition to respect for its members severally. Indeed Leopold is committed to a form of ethical holism and in this regard he inclines to say that the right and wrong of moral doing are a function of the well-being of the community, not of its constituent members. According to this view, it would ethically be permissible to kill individual deer so long as the 'integrity, stability, and beauty' of the deer population were preserved. If there is a situation in which over population threatens the stability and integrity of an entire ecosystem within which the deer live, we might well have an obligation to selectively kill individual deer. It would equally be true in other species as well. Thus, the stability, beauty and dignity of the nature or environment is the prime concern to us. The pertinent question then 


\section{Jurnal Office: Jurnal Pemikiran Ilmiah dan Pendidikan Administrasi Perkantoran}

Vol. 6, No. 2, July-December 2020, Page 131-142

naturally arises why it is reasonable to adopt ethical holism with regard to ecological communities? In this regard, we can find three possible insights in Leopold. Firstly, ethical holism is the most practical approach to make viable decisions concerning the resource environment. Secondly, ethical holism is implied by an epistemological holism inherent in ecology. Thirdly and finally, ethical holism acknowledges the metaphysical reality of ecological wholes.

It is to be noted here that ethical holism stems in part from the failure of more individualistic thinking. This is particularly required for developing non-anthropocentrism. Individualism and subjectivism is detrimental for the comprehensive and cohesive development of environment. In fact, when we think only in terms of individual plants and animals, we embrace misfortune and risky management policies (Bassey, Orji, \& Afolabi, 2020). We have more than sufficient and ample evidence for the abuse and destruction that follows from ignoring the interdependencies within an ecosystem. For Leopold, the destruction of predators can have an impact on the population of deer. He advises us to perceive an ecosystem just like 'thinking as a mountain'. Indeed, when Leopold writes to ranchers, farmers, hunters, and policymakers, he actually tends to adopt this more pragmatic approach to ethical holism.

Where then is the relevance of epistemological holism? What does it actually mean? Epistemological holism follows from the claim that an adequate understanding of ecology can come only from holism, or functionality, or explanations (Nunn \& Dhabi, 2013). For example, a complete understanding of a wolf must include an account or explanation of how that species functions within the ecosystem. Not only a wolf, the same inquiry may be raised in the case of other species as well. Every biotic community has a role to play to maintain the stability, integrity and beauty of nature. As a member of a biotic community, a wolf plays a role in the overall stability and integrity of the system. Thus in a sense, the functional community model of the ecosystem in turn provides a basis for ethical holism. The value of an individual organism is derived in part by its function, role, operation, relationships, and the like. The concept of an ecosystem thus understandably gives reasons for adopting an ethical perspective that grants moral consideration to factors other than individual organisms. The most interesting aspect of Leopold's Land Ethic is that here he conceives land as a living thing. He has, of course, a specific grounds for thinking of land as a living thing. He thinks the creation of the world is made possible through the process of an energy circuit and nothing else. As far as the energy circuit is concerned, the land or land community in the sense of Leopold, has a significant role to play. In this sense, he conceives land as a living organism.

Metaphysical holism provides further reasons for accepting ethical holism. In this regard, Leopold tells us that 'it is possible to regard earth's parts - soil, mountains, rivers, atmosphere, etc., - or organs, or parts, of a coordinated whole' (Nunn \& Dhabi, 2013). The belief that earth is dead is wrong. It arises in part from our incapability to recognize the 'enormously show, intricate, and interrelated functions' of its life process. It makes explicit distinction between metaphysical and ethical holism. In this context Leopold says, "Philosophy, then, suggests one reason why we cannot destroy the earth with moral impurity namely that the 'dead' earth is an organism possessing a certain kind and degree of life, which we intuitively respect as such" (Nunn \& Dhabi, 2013). The point that can be taken care of is that if the earth itself is alive and if we can attribute to it such attributes as health, sickness, growth, and death, we can argue along familiar lines that the earth itself warrants moral consideration. Of course, one thing should be kept in mind that to conceive of the earth or land as a living organism is to conceive and perceive it in a metaphysical sense where the relevance of metaphysical holism actually comes forth. Having said this, still there are various reasons for adopting ethical holism to explain the nature of the biotic wholes in question. There developed various models of ecological systems and each one can have different ethical implications. If that is the case, then how exactly can the biotic community be 
understood? Which model can best describe the activities of ecosystems? Leopold's model, we think, would serve as the best model towards understanding the natural environment. Very interestingly, he conceives the earth as a living organism. Here he relies on the community model of ecology where there is no individual reference. Even besides community model, he equally emphasize on the energy model as well. He says that the land or earth is living in the sense that everything within the earth is being transformed through the energy circuit. He says, plants absorb energy from the sun. This energy again flows through a circuit called the biota which may be represented by a pyramid consisting of layers.

One may be concerned with food flowing through food chains of producers or one may consume energy flowing through circuits. It would make an ethical difference and nothing else. Having said this, Leopold very often emphasizes on our duty to preserve the health of the land and often laments those cases in which the land is dead (Kinzel, 2020). One has to understand the concept of the health and death of earth or land in the metaphorical sense. The health of the earth or land can be understood when viewed as having intrinsic value. Again, the concepts of integrity and stability as maintained by an organism is one thing and the integrity and stability of a community or energy circuit is quite another. These are crucial questions for the land ethic. Thus, in a sense Leopold reasons from ecological factors to normative ethical conclusions. One has to be cognizant of these things while making a sense of the trio-concepts, such as, integrity, stability and beauty to ecosystems. Two vital questions may be thought of in this context. Can such properties attributed to ecosystems? How do ecological facts support the ethical conclusions? What exactly was Leopold's model for understanding ecological wholes? Leopold, in his later writings, abandoned the organic model. However, in his Land Ethic he does not make any systematic distinction in the various models. The reason for this is that his approach in the Land Ethic is holistic in nature. As a result of that he left nothing out and incorporated everything.

\section{DISCUSSION}

Even though Leopold's Land Ethic carries a new concept of land or earth, still it has been criticized by many from different perspectives. There are two important dimensions in Leopold's Land Ethic, first, the move from the facts of ecology to the wholes of ethics, and secondly, the ethical implications of Leopold's holism. The first issue is associated with what philosophers have called 'naturalistic fallacy' and the second issue is deeply rooted on the nature of ecological wholes. In traditional ethics, we are very much aware of the famous philosophical debate or dichotomy between fact and value or alternatively, sometimes known as 'fact-value dichotomy'. It states that there always remains a logical gap between a 'statement of fact' and a 'statement of value'. As a result of that, a value statement or an evaluative statement cannot be logically deduced from a factual statement and vice-versa. A factual statement is known as an 'is-statement' and an evaluative statement is known as an 'oughtstatement'. According to Moore, the proponent of naturalistic fallacy, any attempt to assert something as good or right solely on the basis of description leads us into naturalistic fallacy (Stem, 2019). According to Moore, evaluative terms, such as good, right, etc., are non-natural terms. They cannot be interpreted with regards to descriptive terms. Many would find the naturalistic fallacy in Leopold's position when he goes on to say, that 'a thing is right when it tends to preserve the integrity, stability and beauty of the biotic community and it is wrong when it tends otherwise'.

On the other side, many would conceive that by way of doing this just cited, Leopold actually made an attempt to minimize the gap between 'is' and 'ought'. This might be a teleological reasoning defended by The Aristotelian tradition. In this regard, Leopold has to defend the organic which develop toward a point of stable equilibrium. Thus, with the help of natural scientific descriptions of the normal development of an organic model or whole along with its own identifiable integrity and stability, we 


\section{Jurnal Office: Jurnal Pemikiran Ilmiah dan Pendidikan Administrasi Perkantoran}

Vol. 6, No. 2, July-December 2020, Page 131-142

could determine what is good or bad, right or wrong, healthy or unhealthy, for elements of that system. According to this theory, it can be assumed that predators are good and ought to be protected, because in normal situations they contribute to the stabilisation of populations within the system and thus to its health. Side by side, eliminating or extinguishing exotic species or reintroducing native species is right because it maintains the natural integrity of the ecosystem.

Why should we value the overall integrity or stability of the system itself? In this regard, Leopold says that we could appeal to the role that particular ecosystems plays in the overall stability and integrity of some larger organic whole. Thus, like a heart, a wetland performs a function within some organic whole. Accordingly, it is our general inclination and feeling that would create an internal inertia on the basis of which we feel that we ought to preserve the integrity and stability of an ecosystem. By doing this, we feel, we are promoting the good of some larger whole of which the ecosystem is a part. Following Leopold, we can argue that the earth itself should be considered an organic whole. From ecological perspective it seems clear to us. This line of reasoning simply pushes the open question back a step. The larger whole should be valued because it preserves the well-being of its constituent parts such as, human beings. Instrumental and individualistic reasons are not part of the land ethic. Some teleological goal exists for the entire system. However, many would deny any teleological account towards preconceiving nature as an organic whole along with the theory of organic models. For them, neither ecology nor philosophy in the real sense of the term is responsible for producing a plausible interpretation of what the earth's telos might be.

The other insightful assumption that has been accepted by the Land Ethic of Leopold is to argue that an ecosystem, very similar to an individual organism, goes through developmental stages. Accordingly, the normal developmental progression would thereby provide a basis for evaluating the health and well-being of that system. Unfortunately, this is logical only if we assume the validity of the organic model. But most ecologists have moved away from the organic model. Indeed, there we do not find a single ecosystem that develops over time. What then would be the integrity and stability of this be? The notable point is that we can meaningfully ask this question. Accordingly, it can be said that the leap from ecological fact to ethical value remains an open question. Critics find the same fate in the community model as well. It is claimed that the mainstream ecosystem model does not resolve the problem. In the community model, individuals are related to each other functionally. However, there is little reason to assume a function for the chain itself. Even it would be the case that we might be able to provide a functional evaluation of the roles of individual organisms, particularly, within the food chain. But why should any particular food chain, any particular arrangement of food chain be valued in itself? It is yet to be answered from Leopold's deliberations. Moreover, we have seen even less reason to presume a normative account of energy circuits along with Leopold's line of thinking. Then why is the preservation of the integrity and stability of a food chain or energy circuit good or right?

Of course, there is no question of doubt that Leopold in his Land Ethic has drawn a normative conclusion, such as, 'a thing is right when it tends to preserve the stability, integrity and beauty of the biotic community'. This normative conclusion seems to be derived from the facts of ecology. Even for the sake of argument, if it is assumed that a factual and meaningful basis exists for attributing integrity, stability, and beauty to ecosystems, still in can be asked how these facts are connected to the value conclusions remains an open question. A serious challenge is mounted against Leopold's normative conclusion by those who argue along Aristotelian teleological lines. Their argument is that one can speak of ecological functions in order to achieve the same goals, either as parts within a larger whole or as whole within its own goals. On the basis for Aristotelian teleological sense, we might have some basis of reaching normative conclusions. However, Darwin's account of natural selection makes serious reservations about the meaningfulness of teleological explanation in biology. According to this account, 
members of an ecosystem do not function just the way they do because of some forward looking goal or purpose (). Components of an ecosystem function the way they do because functioning in this way has proved adaptive. But how do predators function within an ecosystem? It is easy to think that wolves exist in order to prey on elk and other species and maintain a natural stability and equilibrium.

But the Darwinian evolution theory suggests that wolves prey on elk and other species because in the past this behavior has proved adaptive. Of course, one should be careful to avoid something that has been overstated. We cannot support ethical judgments by appeal to naturalistic facts. To determine something as right or wrong, we have to look outside the perception of conceiving it as normal or natural. Ecological facts in themselves do not prove that ecological integrity and stability are ethical values. However, the Leopold's Land Ethic responded to such criticisms well. It proposes an ethical extension. For Leopold, ethical revolution is implicit in his extension of ethics to the land and may be thought of as a radical change in human psychology. This change in psychology brought about through moral and ecological education might bridge the gap between is and ought. It should be kept in mind that after Leopold the ethical relation to land cannot be comprehended without preconceiving love, respect and admiration for land. This psychological development is a prerequisite when we talk of land ethic. One has to have a high regard towards the value of land. Land should not be evaluated or valued from economic perspective. Our understanding of the value of land is something intrinsic or inherent and one has to cognize the value of land in the philosophical sense. In this regard Leopold said, "It is inconceivable to me that an ethical relation to land exist without love, respect and admiration for land, and a high regard for its value. By value, I of course mean something far broader than mere economic value; I mean value in the philosophical sense" (Budolfson, 2014) I think that Leopold's ethical holism is directed towards ecological wholes where humans change their attitude towards the land. Here humans' attitude towards land is not arrogant and economical in nature. Land here is treated not as mere resources of use having only instrumental or use value, rather land is the source of energy circuit and the locus of all creation. Only when humans come to love, respect, and admire the land, will they then have reasons to act in ways that benefit it. The question then is: how will humans come to love, respect, and admire the land? In this regard, Leopold said that this can be done by properly understanding ecology. For an ecological valuing of nature, one has to understand ecology. In fact, the natural facts of ecology do not lead directly to ethical conclusions. One has to change attitude and that can, in turn, lead to a change in ethical evaluations.

Thus, it seems to us that after Leopold we value the preservation of an ecosystem not simply because it is natural or normal but because through our ecological knowledge and understanding we love it, respect it, obey it and above all, admire it. In this regard, the role of ecology is focused more toward moral education rather than on normative ethics. As we know Leopold's view of land ethic is that it is in fact an ecological science because he himself claims that land is a living organism and natural resources as well. In what sense, has he claimed that land is a living organism? Certainly, it is not in the common and quite negative sense, but in a pejorative sense. For Leopold, land is living because land is the source of the energy circuit and hence the locus of creation. From a metaphysical sense, land is the mother, the devi, devibasundara from where everything is created. Critics find it hard normative principles in Leopold's Land Ethic. The principle on which Leopold's Land Ethic is based states: "Act in ways that tend to preserve the integrity, stability, and beauty...' (Shaw, 1997) where we can find that it is a straightforward normative principle. Rather it is an exhortation or appeal to get people to think in a certain way. Of course, there is nothing wrong in suggesting that there is an ethical consideration to land. This proposal is in essence, anti-economic because it gives rise to an alternative and challenging the normally accepted way of economic thinking. However, it does not provide independent reason for acting on behalf of the land. 
138| Jurnal Office: Jurnal Pemikiran Ilmiah dan Pendidikan Administrasi Perkantoran

Vol. 6, No. 2, July-December 2020, Page 131-142

As far as holism is concerned, Leopold's Land Ethic faces some serious challenges and criticisms. There are two general concerns underlying these challenges. First, can a meaningful account of ecological wholes be defended? And secondly, are the ethical implications acceptable? The most serious objection that can be raised against ethical holism is that it condones or disregards the good of individuals to the good of the whole. That means, individual good is secondary and the good of the whole is primary. Accordingly, an individual life can be sacrificed for the betterment of the whole. Accordingly, if we define right and wrong with regard to biotic community, it would seem possible to sacrifice individual members, such as, for example, individual human beings (Obilor, Iwundu, Okoroafor, Chima, \& Bello, 2018). Thus, it can be asserted along the line of this theory that the life of an individual can be sacrificed for the betterment of the whole or for the good of the community. Even it seems to us that Leopold himself is willing to condone hunting individual animals to preserve the integrity, stability and the beauty of the biotic community. As humans are equal members of the community, he would seem to be committed logically to the possibility of hunting humans for preserving the integrity, stability and beauty of that community. Such philosophical position of Leopold faces a sharp reaction to many environmentalists. Marti Kheel, a writer and activist, has called Leopold's ethical holism totalitarian and Eric Katz has claimed it 'subverts respect for individuals' (Piccolo, 2020). The most punitive criticism was made by Regan. He labeled Leopold's approach 'environmental fascism'.

According to Regan, it would be extremely difficult to come by a rights based environmental ethics which requires reconciliation between the individualistic nature of moral rights and a more holistic view of nature. It has a great implication that cannot be met by Leopold. In this context Regan says, "The implications of this view include the clear prospect that the individual may be sacrificed for the greater biotic good, in the name of "the integrity, stability and beauty of the biotic community". It is difficult to see how the notion of the rights of the individual could find a home within a view that ... might be fairly dubbed "environmental fascism' (Knight, 1996). All these are very serious charges and the value of Leopold's Land Ethic would be under question if he will not give proper responses to these questions. Here we have good reason to look elsewhere for a satisfactory environmental ethic. When we talk of environmental holism with regard to Leopold's Land Ethic, we are basically inclined towards an extension of moral standing to all natural communities. Accordingly, our perception of ecosystems has moral standing in an extended sense. Now the vital question is: what ought we to do when the good of an ecological community conflicts with the good of an individual? If we believe in anthropocentrism, we can say that the ecological community must be extinguished for the sake of an individual. Because an ecological community has only use or instrumental value and an individual has intrinsic value (Bassey, 2019). On the contrary, if we are the firm believers of non-anthropocentrism, we have a different perception altogether. In such a case we propose to sacrifice the good of an individual for the sake of the good of the natural community. Thus, we have two options. Either we have to override the interests of humans or we abandon the pretense and allow the humans interest to take precedence. If we take the first option, we face the problem of fascism charge and if we take the second, then we have to abandon environmental holism.

Philosopher Don Marietta suggests another response. He says that the concept of ethical holism has a multiplicity of implications. In one sense, Leopold's integrity and stability might suggest that the only source of right and wrong is the good of the biotic community or it might hint at that the source of right and wrong lies with the good of the community. He further inclines to say that we cannot justify treating the good of the biotic community as the only or necessarily the most important source of right and wrong. These positions would be treated as extremely reductionist where humans are being treated only as biological entities. According to Marietta, humans are certainly more than biological entities and a satisfactory ethics must take into account the wide range of morally relevant factors about humans 
139

(MacCleery, 2000). Thus, to define humans merely by their biological nature is neither just nor right. Ethical holism should introduce a new source of understanding of right and wrong into ethics. In such a case we can perhaps overcome the charge of environmental fascism raised against Leopold. In a case like that we should recognize that we face complex moral situations with a few specific and overriding rules that determine exactly what we should do. Thus, in a specific sense, holism draws our attention to an intricacy that we may have missed otherwise. It does not necessarily commit us to environmental fascism.

This work thinks that Leopold's ideas of integrity and stability should be viewed as normative for human character, such as, our attitudes, dispositions, our manner of thinking and wishing. These may be attributed as the virtues of humans from environmental perspective. It proposes the type of person we should be, a trait of character, not the specific acts one should perform. According to Moline, there are a section of critics who adhere to the view that the so-called direct and indirect holism are nothing but the two sides of the same coin, they are in the real sense of the term indistinguishable. If there is an underlying distinction between direct and indirect holism and if the direct holism is fascistic, then indirect holism would also be fascistic. If it would not be the case then there is no point in saying the relevance of indirect holism according to the critics. This work think that this criticism would be treated as substantive only if one can have an unambiguous knowledge about the concept of environmental holism. However, it was pointed out time and again by Leopold that even the ecologists do not know exactly what will preserve the integrity, stability and beauty of the biotic community. Modern peoples are the perceivers of knowledge and they do believe that knowledge should be justified with sound evidence. They assume that science knows what makes the community clock tick. The scientist is equally sure that he does not. The scientist knows that the biotic mechanism is so complex that its workings 'may never be fully understood' (Nwoye, 2018). Thus, nobody can deny the complexity of ecosystems and nobody deny that they undergo constant change. Accordingly, it cannot be presumed that we ever know anything with outmost certainty that will or will not preserve the stability, integrity and the beauty of the biotic community. This, it may be criticized by saying that Leopold's principle as stated above would be empty and irrelevant.

How would we then integrate Leopold's appreciation of the ecological complexity of nature? There is no question of doubt that Leopold's land ethic appeared as revolutionary as far as our understanding of natural community is concerned. His theory was certainly not based on myths or prejudices; rather he argues in favor of biological science. In the same breath we cannot forfeit the complexity of nature as well. Indeed ecology teaches that natural biotic systems are extremely complex. Accordingly, we need to abandon the mechanistic view of nature and be suspicious of any abrupt and human wrought changes to it. Besides, we have to be cautious and be sensitive to moral complexity as well. Putting everything into perspective, we conclude that ecological ethics is fundamentally indeterminate. As a result of that we would no longer be in a position to know what the ethically correct act would be. We are no longer in a position to know about an ecosystem to understand the consequences of our actions very similar to the case in our external world. Our approach of valuing nature might be pulling us in different directions. Accordingly, in such cases we should be guided by those attitudes, dispositions, and practices that have lean towards preserving the integrity, stability and beauty of ecosystems (Bassey 2020). These are attitudes of love, respect, care, and admiration. All these would imply a relatively conservative approach to natural systems. The main objectives are to aim for: natural environmental changes rather than artificial changes; the cultivation of native plants and animals; the achievement of slow rather than rapid changes; and the fostering of biological rather than mechanical, artificial and manufactured solutions to environmental problems (Osuala \& Nyok 2018).

Now let us pass on to examine the final question which states whether Leopold's holistic ethics as a meaningful account of ecological wholes is defensible? We have already stated that there are various theories developed by ecologists as different models of an ecosystem which are in some sense or other addressed as organic, community, energy circuit etc. Is there anyone that would be compatible with the 


\section{Jurnal Office: Jurnal Pemikiran Ilmiah dan Pendidikan Administrasi Perkantoran}

Vol. 6, No. 2, July-December 2020, Page 131-142

land ethic of Leopold? We have seen that Leopold adopted organic model of ecosystems as he conceives land itself as a living organism, of course, in a pejorative sense. We think that this model best be suited for the Land Ethic of Leopold. He treats ecosystem as an organic wholes where the facts of ecology and the values implicit in such concepts as integrity and stability, health and well-being (Njar \& Enagu 2018). Having said this, it should be kept in mind that while talking of the holism of ecosystem we have to go beyond the biological concept of living organisms. In this sense, it may be said that the organic model of ecological systems is inadequate. The classical refutation of the organic model is found in the writings of Tansley where an ecosystem was viewed as organisms only in the metaphysical sense. This is because of the fact that individuals within an ecosystem could exist outside the organism. According to Tansley, ecosystems do not have the 'unity and definiteness 'of real organisms, and their constituent parts are quite capable of moving into other systems and becoming full members of them (van der Valk 2014). This clearly suggests that the members of an ecosystem are quite unlike the organs of the body. Accordingly, Leopold's holism should be understood within the functional community model where members of an ecosystem are not understood as parts to a whole or as organs to a body but as functionally dependent upon each other. Here an individual organism is identified as part of the biotic community or the food chain, by reference to what it eats and what eats it. Thus, it can be said that the arrangement of individual organisms and their relations to one another are what constitute the system.

\section{CONCLUSION}

The well-being of natural community consists of its integrity and stability. As a result of that human beings are encouraged to act out of love, respect and admiration for the whole biotic community. This is made possible only in so far as this community has some interests of its own, i.e., not as a means to an end, but as an end in itself. When we talk of environmental holism, it is reasonable to hold that we can love and respect a biotic community because it has interests and its interests rest on its integrity and stability. Are biotic communities the kind of things that possess integrity and stability? We think that at a certain point it can. A small pond, for example, can be said to possess integrity and stability if it is not drained, if its various biotic populations remains stationary, if the climate remain constant, if artificial or nonnative elements are not added and so on. Do ecosystems remain stable over time? It may not be the case. It is revealed that through natural biological, chemical, geological, and climate forces, biotic communities evolve into different types of ecosystems. Thus, we are faced with a choice. Either interfere with these natural processes in order to preserve a particular integrity and stability, or allow these natural processes to continue and abandon the most obvious sense of integrity and stability. Our apprehension is that biotic community perhaps can be understood to refer not to the particular members of the community or to a particular arrangement of those members but to the conditions under which the biological processes and relationships can be preserved. Accordingly it can be presumed that an ecosystem has integrity and stability to the degree that it is capable of sustaining biological process. This proposal again faces serious challenges. First, it might assign too much importance to the concept of the health of an ecosystem based on intrinsic value. Second, it could be argued that we ought to preserve the integrity and stability of a system not because it has value in itself but because it contributes to the well-being of other things that have intrinsic value.

The other important point is that in service to the well-being of the whole, one will sacrifice the well-being of the individuals. Here we extend membership for moral consideration to the land without disavowing an initial and prior value that characterizes the inner circles. But what we do in cases where conflict exists between responsibility to the inner most circle, i.e., to myself and my family, and responsibility to outer circles, which include ecosystems and wilderness areas? The debate continues 
without finding a suitable and acceptable conclusion. This works' position is that although Leopold's Land Ethic opened up a new chapter within the sphere of environmental ethics, but there is no point in saying that his theory has been accepted without criticism and question .There is no doubt that, his writing provides inspiration for everyone concerned with environmental ethics. He argues that ecological wholes are worthy of serious moral consideration. Having said this, such consideration turns out to be in the form of direct or indirect moral standing that cannot be ignored after Leopold.

\section{REFERENCE}

Bassey, S. A. (2019). 'Anthropoholism'As an Authentic Tool for Environmental Management. Journal of Environmental Pollution and Environmental Modelling, 2(3), 160-168.

Bassey, S., Orji, M., \& Afolabi, O. (2020). An Overview of Materialistic and Unified approach to Man Nature Relationship. GNOSI: An Interdisciplinary Journal of Human Theory and Praxis, 3(3), $17-28$.

Budolfson, M. (2014). Why the standard interpretation of Aldo Leopold's Land Ethic is mistaken. Environmental Ethics, 36(4), 443-453.

Edame, G., Effiong, C., \& Ackuk, E. (2014). Agriculture, Forestry and Water Resources Management: A Panacea for Sustainable Development in Nigeria. Academi Journal of Interdisiplinary Studies, 3(4), 373-373.

Emmanuel, D. (2020). Epigenetics: How the environment influences our genes. In Encyclopedia of the Environment.

Heffeman, J. (1982). The Land Ethic: A Critical Appraisal. Environmental Ethics, 4(3), 235-247.

Jürgens, U. M. (2014). Compassionate Coexistence: Personizing the Land in Aldo Leopold's Land-Ethic. Journal of Evolurtion and Technology, 24(3), 60-64.

Kinzel, K. (2020). Method and Meaning: Ranke and Droysen on The Historian's Disciplinary Ethos. History and Theory, 59(1), 22-41.

Knight, R. L. (1996). Aldo Leopold, the Land Ethic, and Ecosystem Management. The Journal of Wildlife Management, 60(3), 471-474.

MacCleery, D. (2000). Aldo Leopold's land ethic: is it only half a loaf? Journal of Forestry, 5-7.

Njar, B. I., \& Enagu, D. A. (2018). Development and Environmental Sustainability in Nigeria: An African Perspective. GNOSI: An Interdisciplinary Journal of Human Theory and Praxis, 2(1), 3747.

Nunn, R., \& Dhabi, A. (2013). An Argument for Holism Part 2 (an editorial opinion piece). Asian EFL Journal, 15(2), 9-23.

Nwoye, L. (2018). Ethical Issues in Arms Technology. GNOSI: An Interdisciplinary Journal of Human Theory and Praxis, 1(1), 25-33. 
142 Jurnal Office: Jurnal Pemikiran Ilmiah dan Pendidikan Administrasi Perkantoran

Vol. 6, No. 2, July-December 2020, Page 131-142

Obilor, O., Iwundu, K., Okoroafor, F., Chima, E., \& Bello, M. (2018). Democracy and National Development: A Focus on Nigeria. GNOSI: An Interdisciplinary Journal of Human Theory and Praxis, 1(2), 1-8.

Osuala, A. N., \& Nyok, E. I. E. (2018). New Twist to Political Corruption in 4th Republic Nigeria given Non-Human Animals Stealing millions: A Case for the Defense of Animal Rights. GNOSI: An Interdisciplinary Journal of Human Theory and Praxis, 1(2), 15-37.

Piccolo, J. (2020). Celebrating Aldo Leopold's land ethic at 70. Conservation Biology, 34(6), 1586-1588.

Rolston, H. (2000). The land ethic at the turn of the millennium. Biodiversity and Conservation, 9(8), $1045-1058$.

Shaw, B. (1997). A Virtue Ethics Approach to Aldo Leopold's Land Ethic. Environmental Ethics, 19(1), 53-66.

Stem, A. (2019). The Metaphysics of Meaning. The Fall of Language , 29-55.

van der Valk, A. G. (2014). From Formation to Ecosystem: Tansley's Response to Clements' Climax. Journal of the History of Biology, 47(2), 293-321

Walck, C., \& Strong, K. (2001). Using Aldo Leopold's Land Ethic to Read Environmental History: The Case of the Keweenaw Forest. Organization and Environment, 14(3), 261-289. 